ISSN = 1980-993X - doi:10.4136/1980-993X
www.ambi-agua.net
E-mail: ambi-agua@agro.unitau.br
Tel.: (12) 3631-8004

\title{
Effects of ferric ions on the catalytic ozonation process on sanitary landfill leachates
}

\author{
doi: 10.4136/ambi-agua.958 \\ André Luiz de Souza*; Hélcio José Izário Filho; André Luiz de Castro Peixoto; Oswaldo \\ Luiz Cobra Guimarães; Carla Cristina Almeida Loures; Gisella Rossana Lamas \\ Samanamud; Messias Borges Silva
Universidade de São Paulo (USP), Escola de Engenharia de Lorena (EEL), Departamento de Engenharia Química (LOQ), Lorena-SP, Brasil,
*Autor correspondente: e-mail: andrelsfonte@hotmail.com, alcpeixoto@yahoo.com.br, helcio@dequi.eel.usp.br, cobraguimaraes@uol.com.br, ccaloures@hotmail.com, zeldals@hotmail.com, messias@dequi.eel.usp.br

\begin{abstract}
Leachates exhibiting an unstable ratio of biochemical oxygen demand (BOD) and chemical oxygen demand (COD) of approximately 0.45 are typical of new landfills in the City of Cachoeira Paulista, Brazil. Although the organic matter portion is bio-treatable, the presence of refractory leached organic material requires unconventional effluent-treatment processes. Leachate treatment with ozone oxidation, in the presence of ferric ions, acts as catalyst in the formation of hydroxyl radicals. Ozone was obtained by corona-discharge from high-purity $\mathrm{O} 2$ gas. The treatment was performed in natura in a jacketed borosilicate glass reactor containing $900 \mathrm{ml}$ of leachate. The analyzed response variable was expressed as the concentration of dissolved organic carbon (DOC). In order to determine the optimal proportions to produce the greatest degradation rate for organic materials, variations in experimental $\mathrm{O}_{2}$ flow-fed to the generator, the $\mathrm{Fe}$ (iii) concentration, and the output of the ozonator were conducted over two experimental runs. Experimental models showed a DOC degradation on the order of $81.25 \%$.
\end{abstract}

Keywords: Wastewater treatment, leachate, advanced oxidation processes, catalytic ozonation, design of experiments.

\section{Efeitos dos íons férricos no processo de ozonização catalítica do chorume de aterros sanitários}

\section{RESUMO}

O Chorume da cidade de Cachoeira Paulista apresenta uma relação DBO/DQO de aproximadamente 0,45. Apesar de apresentar fração de matéria orgânica biotratável, existe também a presença de material orgânico refratário no lixiviado, sendo necessário a utilização de processo de tratamento não convencional de efluentes. Utilizou-se neste tratamento o oxidante ozônio, na presença do íon férrico, o qual atua como catalisador na formação de radicais hidroxilas. O ozônio foi gerado por um sistema de discarga elétrica (efeito corona) com passagem de oxigênio de alta pureza. Foram tratados $900 \mathrm{ml}$ de chorume in natura em um reator de borossilicato encamisado. A variável resposta analisada foi a concentração do 
SOUZA, A. L.; IZARIO FILHO, H. J.; PEIXOTO, A. L. C.; GUIMARAES, O. L. C.; LOURES, C. C. A.; LAMAS SAMANAMUD, G. R.; SILVA, M. B. Effects of ferric ions on the catalytic ozonation process on sanitary landfill leachates. .Ambi-Agua, Taubaté, v. 8, n. 1, p. 48-61, 2013. (http://dx.doi.org/10.4136/ambiagua.958)

Carbono Orgânico Dissolvido (DOC). Foram utilizados dois planejamentos exploratórios variando a vazão de $\mathrm{O}_{2}$ alimentada ao gerador, concentração de ferro (III) e potência do ozonizador, a fim de encontrar o ponto ótimo proporcional a maior taxa de degradação da matéria orgânica. Nestes planejamentos exploratórios foi possível se atingir uma porcentagem de degradação de DOC da ordem de 81,25\%.

Palavras-chave: Tratamento de efluente, chorume, processos oxidativos avançados, ozonização catalítica, planejamento de experimentos.

\section{INTRODUCTION}

The organic liquids produced by biological degradation processes, which are characteristically dark with an unpleasant odor, is a serious problem in landfills. Unlike rainwater, this liquid percolates through the mass of the landfill creating a toxic leachate. Leachates are generated primarily by water rich in salts, heavy metals, and organic matter. According to Costa (2002), the constituent concentrations in leachates vary with the composition of deposited solid wastes, the volume of such wastes, and ambient conditions such as precipitation, humidity, available oxygen, temperature, and mean $\mathrm{pH}$.

Many wastewater treatment processes have been used for the treatment of leachate. The most frequently employed are: aerobic and anaerobic degradation systems, chemical oxidation, chemical precipitation, coagulation-flocculation, activated-carbon absorption and membrane-based processes, as noted by Amokrane et al. (1997), Shen and Wang (2002), and Ozturk et al. (2003). Landfill leachate treatment in Brazil, as noted by Caetano (2009), is performed primarily for industrial-effluent treatment and exclusively by physiochemical processes.

Advanced oxidative processes (AOP) have been extensively studied for applicability in the treatment of differing types of industrial waste as well as for leachate contaminants that show problematic responses to conventional treatments.

In the treatment of leachate using AOPs, ozone stands out for its excellent results in the removal of color, attributed mainly to a direct attack on chromophore groups. In several works such as Marttinen et al. (2002) and Wu et al. (2004), treatment with ozone has been used as a pretreatment step for biological systems or as a post-treatment process for coagulation/flocculation, as per Monje-Ramirez and Orta de Velasquez (2004).

Both Monje-Ramirez and Orta de Velasquez (2004), Javier Rivas et al. (2004) reported an elevation in biodegradability for various matrices utilizing coagulation/flocculation with subsequent ozonation. Generally, the literature notes that ozonation promotes significant increases in effluent biodegradability and in improving the efficiency of sequential biological processes. Ozone-based systems were reported by Calli et al. (2005) to remove $85 \%$ of the remnant COD after anaerobic-upflow in reduced-scale applications. Catalytic ozonization is an effective method for removal of various organic compounds in water and for treating wastewater. This method is mainly used, however, at a laboratory scale as reported by Kasprzyk-Hordern et al. (2003) and Peixoto (2008). Equations 1 through 7 describe proposed Fe(ii) reactions with ozone as described by Peixoto (2008) and Legube and Leitner (1999). Notably, the utility of $\mathrm{Fe}^{2+}$ in catalytic ozonization is restricted to acidic media once higher $\mathrm{pH}$ values generate ionic precipitation, as described by Assalin and Duran (2007). 
SOUZA, A. L.; IZARIO FILHO, H. J.; PEIXOTO, A. L. C.; GUIMARAES, O. L. C.; LOURES, C. C. A.; LAMAS SAMANAMUD, G. R.; SILVA, M. B. Effects of ferric ions on the catalytic ozonation process on sanitary landfill leachates. .Ambi-Agua, Taubaté, v. 8, n. 1, p. 48-61, 2013. (http://dx.doi.org/10.4136/ambiagua.958)

$$
\begin{aligned}
& \mathrm{Fe}^{2+}+\mathrm{O}_{3} \rightarrow \mathrm{Fe}^{3+}+\mathrm{O}_{3}^{--} \\
& \mathrm{O}_{3}{ }^{-}+\mathrm{H}^{+} \leftrightarrow \mathrm{HO}_{3} \rightarrow \mathrm{OH}+\mathrm{O}_{2} \\
& \mathrm{Fe}^{2+}+\mathrm{OH} \rightarrow \mathrm{Fe}^{3+}+\mathrm{OH} \\
& \text { Balance: } 2 \mathrm{Fe}^{2+}+\mathrm{O}_{3}+2 \mathrm{H}^{+} \rightarrow 2 \mathrm{Fe}^{3+}+\mathrm{O}_{2}+\mathrm{H}_{2} \mathrm{O} \\
& \mathrm{Fe}^{2+}+\mathrm{O}_{3} \rightarrow(\mathrm{FeO})^{2+}+\mathrm{O}_{2} \\
& (\mathrm{FeO})^{2+}+\mathrm{Fe}^{2+}+2 \mathrm{H}^{+} \rightarrow 2 \mathrm{Fe}^{3+}+\mathrm{O}_{2}+\mathrm{H}_{2} \mathrm{O} \\
& \text { Balance: } 2 \mathrm{Fe}^{2+}+\mathrm{O}_{3}+2 \mathrm{H}^{+} \rightarrow 2 \mathrm{Fe}^{3+}+\mathrm{O}_{2}+\mathrm{H}_{2} \mathrm{O}
\end{aligned}
$$

Equations 1 through 7 demonstrate that the reaction mechanism forming Fe(iii) ions and radical $\mathrm{O}_{3}^{-{ }^{-}}$and, from this reaction, hydroxyl radicals, is the transfer of electrons from the reduced metal to ozone. In the presence of excessive Fe(ii), hydroxyl radicals can oxidize $\mathrm{Fe}(\mathrm{ii})$ in 1 second, providing a stoichiometric ratio of 0.5 moles of ozone per mole of ferrous ion as described in Peixoto (2008) and Legube and Leitner (1999).

The goal of this work was to report on results for an optimized treatment process on leachate from the City of Cachoeira Paulista, State of Sao Paulo, Brazil. Effluent degradation was accomplished through catalytic ozonization using ferric iron as a catalyst for the generation of hydroxyl radicals. The use of ferric iron as an abundant chemical species enhanced the recalcitrant oxidation of organic matter by capitalizing on the intrinsic chemical characteristics of leachate.

\section{MATERIAL AND METHODS}

\subsection{Sampling and storage}

Leachate used in this project was provided by VSA Corporation in the City of Cachoeira Paulista, State of Sao Paulo. A single $100 \mathrm{~L}$ sample collected and stored at $4{ }^{\circ} \mathrm{C}$.

\subsection{Degradation of leachate by catalytic ozonation}

All stages of leachate treatment were carried out at facilities in the City of Cachoeira Paulista using a jacketed borosilicate glass reactor. The lid of the reactor was made of Nylon 6. Ozone was added to the chemical reactor through the base of the vessel using a plate of sintered glass. Slurry units of $900 \mathrm{ml}$ were used in all experiments at a constant $\mathrm{pH}$ of $2.0 \pm 0.1$. The $\mathrm{pH}$ was measured prior to the initiation of reactions and modified when necessary through the controlled addition of sulfuric acid. The design of the reactor lid facilitates the measurement and control for process variables during the input of the gas mixture $\left(\mathrm{O}_{2}\right.$ and $\left.\mathrm{O}_{3}\right)$ and the collection of reaction product aliquots. Any unreacted gas mixture was left in the inlet to control and adjust the $\mathrm{pH}$ of the reaction medium.

Ozone was generated in an $\mathrm{O}_{2}$ to $\mathrm{O}_{3}$ conversion using an AUJETM, MV Model 01 by dielectric barrier (corona) electric discharge at $220 \mathrm{~V}, 100 \mathrm{~W}$ maximum, and a 2-bar maximum working-pressure. The $\mathrm{AGA}^{\mathrm{TM}}$ ozone generator was fed with oxygen at $99.99 \%$ purity.

\section{3. $\mathrm{O}_{3}$ Concentration Measurement}

$\mathrm{O}_{3}$ concentration quantification was performed by aeration into a solution of $\mathrm{KI}$ in a sulfuric acid medium using iodimetric titration consistent with indirect titration processes. As per Vogel (1981), the formation of the triiodide ion $\left(\mathrm{I}_{3}{ }^{-}\right)$, a stable and soluble reaction product having same number of equivalents to ozone, is obtained as shown in Equations 8, 9 and 10. 
SOUZA, A. L.; IZARIO FILHO, H. J.; PEIXOTO, A. L. C.; GUIMARAES, O. L. C.; LOURES, C. C. A.; LAMAS SAMANAMUD, G. R.; SILVA, M. B. Effects of ferric ions on the catalytic ozonation process on sanitary landfill leachates. .Ambi-Agua, Taubaté, v. 8, n. 1, p. 48-61, 2013. (http://dx.doi.org/10.4136/ambiagua.958)

$$
\begin{aligned}
& \mathrm{I}^{-}+\mathrm{O}_{3} \rightarrow \mathrm{IO}_{3}{ }^{-} \\
& \mathrm{IO}_{3}{ }^{-}+8 \mathrm{I}^{-}+6 \mathrm{H}^{+} \rightarrow 3 \mathrm{I}_{3}^{-}+3 \mathrm{H}_{2} \mathrm{O} \\
& 9 \mathrm{I}^{-}+\mathrm{O}_{3}+6 \mathrm{H}^{+} \rightarrow 3 \mathrm{I}_{3}^{-}+3 \mathrm{H}_{2} \mathrm{O}
\end{aligned}
$$

In Equation 8, ozone is converted to an iodide ion that simultaneously reduces to a triiodide ion (Equation 9). Equation 10 generalizes the process of oxidation-reduction between ozone (reduced) and iodide ion (oxidized).

After the reaction process, based on set durations for each measurement, the triiodide ion concentration was measured by the standard sodium thiosulfate titrate as shown in Equation 11 .

$$
6 \mathrm{Na}_{2} \mathrm{~S}_{2} \mathrm{O}_{3}+3 \mathrm{I}_{3}^{-} \rightarrow 3 \mathrm{Na}_{2} \mathrm{~S}_{4} \mathrm{O}_{6}+6 \mathrm{NaI}+3 \mathrm{HI}
$$

\subsection{Experimental design: design of process variables in catalytic ozonation}

An optimized $\mathrm{O}_{3} / \mathrm{Fe}^{3+}$ relationship was obtained with randomized trials of catalytic process variables as per the experimental matrix shown in Table 1.

Table 1. Experimental factorial matrix $2^{2}$ : (A) as $\mathrm{mg} \mathrm{L}^{-1}$ concentrations of $\mathrm{Fe}^{3+}$ and (B) as $\mathrm{mg} \mathrm{h}^{-1}$ feed of $\mathrm{O}_{3}$.

\begin{tabular}{ccc}
\hline Experiment & Factor A & Factor B \\
\hline 1 & 5 & 508 \\
2 & 15 & 508 \\
3 & 5 & 715 \\
4 & 15 & 715 \\
5 & 10 & 590 \\
6 & 10 & 590 \\
7 & 10 & 590 \\
8 & 10 & 590 \\
\hline
\end{tabular}

The $\mathrm{pH}$ was kept constant at $2.0 \pm 0.1$ throughout each 3 -h reaction duration (Table 1). Aliquots were collected at 20 min intervals. The process efficiency was evaluated in terms of the percentage reduction of DOC.

After completing the first experiments as defined in (Table 1), an optimization of input factor levels for $\mathrm{O}_{3}$ and $\mathrm{Fe}^{3+}$ through the execution of another experimental set-up (Table 2) was conducted to achieve a maximum effluent degradation.

In the second experimental design (Table 2), concentration levels of ferric ions changed, as did the feed's mass flow rate in relation to $\mathrm{O}_{3}$, presented in Table 1 . A reaction duration of $1 \mathrm{~h}$ was established for the subsequent set of experiments (Table 2) with samples collected every $10 \mathrm{~min}$. 
SOUZA, A. L.; IZARIO FILHO, H. J.; PEIXOTO, A. L. C.; GUIMARAES, O. L. C.; LOURES, C. C. A.; LAMAS SAMANAMUD, G. R.; SILVA, M. B. Effects of ferric ions on the catalytic ozonation process on sanitary landfill leachates. .Ambi-Agua, Taubaté, v. 8, n. 1, p. 48-61, 2013. (http://dx.doi.org/10.4136/ambiagua.958)

Table 2. Experimental factorial matrix $2^{2}$ : (A) as $\mathrm{mg} \mathrm{h}^{-1}$ concentrations of $\mathrm{Fe}^{3+}$ and (B) as $\mathrm{mg} \mathrm{h}^{-1}$ feed of $\mathrm{O}_{3}$.

\begin{tabular}{c|cc}
\hline Experiment & Factor A & Factor B \\
\hline 1 & 25 & 470 \\
2 & 100 & 470 \\
3 & 25 & 508 \\
4 & 100 & 508 \\
5 & 50 & 439 \\
6 & 50 & 439 \\
7 & 50 & 439 \\
8 & 50 & 439 \\
\hline
\end{tabular}

\section{RESULTS AND DISCUSSION}

\subsection{Analyzing the efficiency of the process}

The physical-chemical characterization of leachate slurry was done according to state and federal regulatory standard definitions for São Paulo and Brazil, inclusive of $\mathrm{pH}$, color, COD, BOD, DOC, turbidity, organic-N, N-ammonia and phosphorus.

Table 3 presents the resultant physiochemical properties for fresh leachate from the City of Cachoeira Paulista, Sao Paulo State before and after 60 min of treatment by homogeneous catalytic ozonation.

Table 3. Physiochemical parameter values for landfill leachate from the City of Cachoeira Paulista, São Paulo State, before and after 60 min of treatment by homogeneous catalytic ozonation.

\begin{tabular}{|c|c|c|c|c|c|}
\hline \multirow{2}{*}{ Parameters } & \multicolumn{2}{|c|}{ Leachate } & \multirow{2}{*}{$\begin{array}{l}\text { Literature } \\
\text { Values }\end{array}$} & \multirow{2}{*}{ References } & \multirow{2}{*}{$\begin{array}{c}\text { Releasing } \\
\text { Patterns* }\left(\mathrm{mg} \mathrm{L}^{-1}\right)\end{array}$} \\
\hline & In natura & Treatment & & & \\
\hline Aspect & Turbid & Limpid & - & - & Absence \\
\hline Real Color (Pt-Co) & 1412 & 42.35 & - & - & Absence \\
\hline Turbidity (NTU) & 409 & 14.40 & - & - & $5-9$ \\
\hline $\mathrm{pH}$ & 7.80 & 7.0 & $7.2-8.6$ & $* *$ & 8 \\
\hline Odor & Irritant & Absence & - & - & - \\
\hline $\mathrm{COD}\left(\mathrm{mg} \mathrm{O}_{2} \mathrm{~L}^{-1}\right)$ & 1032 & 389.6 & $190-22300$ & $* *$ & 60 \\
\hline $\mathrm{BOD}_{5}\left(\mathrm{mg} \mathrm{O}_{2} \mathrm{mg} \mathrm{L}^{-1}\right)$ & 476.1 & 185.0 & $<20-8600$ & $* *$ & - \\
\hline $\mathrm{BOD}_{5} / \mathrm{COD}$ & 0.45 & 0.475 & $0.02-0.80$ & $* *$ & - \\
\hline $\operatorname{COD}\left(\mathrm{mg} \mathrm{L}^{-1}\right)$ & 465.5 & 87.26 & $70-27700$ & $* * *$ & - \\
\hline Phosphorus (mg L ${ }^{-1}$ ) & 10.41 & 1.58 & $0.1-15$ & $* *$ & - \\
\hline $\mathrm{N}-\mathrm{NH}_{3}\left(\mathrm{mg} \mathrm{L}^{-1}\right)$ & 0.45 & $<0.01$ & $0.4-1800$ & $* *$ & - \\
\hline N-organic $\left(\mathrm{mg} \mathrm{L}^{-1}\right)$ & 6.19 & 0.58 & $5-1200$ & $* *$ & - \\
\hline
\end{tabular}

* Article 18 CETESB and resolution CONAMA 357/05. (-) Not Specified.

**Souto and Povinelli (2006); Caetano (2009).

**** Pohland and Harper (1986); Rita (2002). 
SOUZA, A. L.; IZARIO FILHO, H. J.; PEIXOTO, A. L. C.; GUIMARAES, O. L. C.; LOURES, C. C. A.; LAMAS SAMANAMUD, G. R.; SILVA, M. B. Effects of ferric ions on the catalytic ozonation process on sanitary landfill leachates. .Ambi-Agua, Taubaté, v. 8, n. 1, p. 48-61, 2013. (http://dx.doi.org/10.4136/ambiagua.958)

The oxidation process showed a post-treatment COD reduction value of approximately $62 \%$. However, the leachate remained recalcitrant to chemical treatment after catalytic ozonation at a $\mathrm{BOD}_{5} / \mathrm{COD}$ of approximately 0.48 .

According to Castilhos Jr. (2006), BOD concentrations and COD reductions tend to lessen over time. However, BOD decreases more rapidly than COD due to persistent recalcitrant organic matter in the leachate.

It is theoretically possible to use leachate maturity as a BOD/COD parameter, specifically: a BOD/COD of $>0.5 \mathrm{mg} \mathrm{L}^{-1}$ indicates a new and unstable landfill as described by Peixoto (2008).

Effluent color and turbidity after AOP treatment showed a respective reduction of $97 \%$ and $96 \%$. Since color is a legally-defined characteristic, catalytic ozonation proved to be concurrently effective for the removal of both color and turbidity in tested samples. Color and turbidity intensity are directly related to the presence of fulvic and humic acids, possibly resultant from the oxidation process of other species, whose complementary colors absorb radiation in the UV spectral region. Ammonia was not detected after treatment and organic nitrogen was reduced at approximately $91 \%$. This indicates that the process is effective for the treatment of ammonia and organic compounds. Total phosphorus was reduced by $85 \%$, indicating oxidized phosphorus is a less-soluble species than seen under catalytic ozonization as per Peixoto (2008).

Table 4 shows the experimental results for COD reduction treatment obtained by catalytic ozonization as per the experimental design factorial matrix $2^{2}$ shown in Table 1.

Table 4. Percentage of DOC reduction for experimental factorial matrix $2^{2}$ (with center point in quadruplicate).

\begin{tabular}{c|cc|c}
\hline Experiment & $\begin{array}{c}\text { Factor A }\left[\mathbf{F e}^{\mathbf{3 +}}\right] \\
\mathbf{m g ~ L}^{-\mathbf{1}}\end{array}$ & $\begin{array}{c}\text { Factor B } \\
\mathbf{O}_{\mathbf{3}} \mathbf{f e e d}\left(\mathbf{m g ~ h}^{\mathbf{- 1}}\right)\end{array}$ & $\begin{array}{c}\text { \% Reduction } \\
\text { in DOC }\end{array}$ \\
\hline 1 & 5 & 508 & 68 \\
2 & 15 & 508 & 69 \\
3 & 5 & 715 & 67 \\
4 & 15 & 715 & 66 \\
5 & 10 & 590 & 68 \\
6 & 10 & 590 & 69 \\
7 & 10 & 590 & 68 \\
8 & 10 & 590 & 66 \\
\hline
\end{tabular}

Table 4 shows the experimental results of DOC reduction obtained by catalytic ozonization treatment, as seen in Table 1.

The efficiency of processing the leachate slurry was similar for the entire experimental activity with a slight variation between the values shown. This is in the same order of magnitude as the quadruplicate or estimated center-point error.

This finding suggests 5 to $15 \mathrm{mg} \mathrm{L}^{-1}$ concentrations of ferric ions are insufficient in promoting the in situ generation of hydroxyl radicals from the reaction with molecular ozone, as seen in Column $\mathrm{F}$ in Table 5. 
SOUZA, A. L.; IZARIO FILHO, H. J.; PEIXOTO, A. L. C.; GUIMARAES, O. L. C.; LOURES, C. C. A.; LAMAS SAMANAMUD, G. R.; SILVA, M. B. Effects of ferric ions on the catalytic ozonation process on sanitary landfill leachates. .Ambi-Agua, Taubaté, v. 8, n. 1, p. 48-61, 2013. (http://dx.doi.org/10.4136/ambiagua.958)

Table 5. Analysis variance (ANOVA) obtained from the average of DOC reduction values according to the experimental factorial matrix $2^{2}$ for catalytic ozonization treatment.

\begin{tabular}{l|ccccc}
\hline \multicolumn{1}{c|}{ Factors } & $\begin{array}{c}\text { Sum of } \\
\text { Squares }\end{array}$ & $\begin{array}{c}\text { Degrees of } \\
\text { Freedom }\end{array}$ & $\begin{array}{c}\text { Mean sum of } \\
\text { Squares }\end{array}$ & F & P \\
\hline${\mathrm{A}-\mathrm{Fe}^{3+}}^{3+}$ & 42.7 & 1 & 42.7 & 11.2 & 0.044285 \\
$\mathrm{~B}-\mathrm{O}_{3}$ & 7.3 & 1 & 7.3 & 1.9 & 0.260404 \\
Interactions (AB) & 0.2 & 1 & 0.2 & 0.1 & 0.827295 \\
Error & 11.5 & 3 & 3.8 & & \\
Total & 61.7 & 6 & & & \\
\hline
\end{tabular}

Experimental data shown in Table 5 confirm the absence of synergism between the first order factors for ferric ions and ozone. As with any catalytic chemical reaction, it is essential to adjust the ratio of chemical reagents to the catalyst. Degradation reactions for complex effluents such as leachates therefore require the attainment of an optimal ratio between the oxidizing agent ozone and the ferric ion catalyst.

Table 6 shows experimental results of slurry degradation obtained from higher concentrations of ferric ion in the reaction medium. Table 7 indicates the results of the ANOVA test for the second experimental set.

Table 6. Percent reductions in DOC under experiments for catalytic ozone.

\begin{tabular}{c|cc|c}
\hline Experiment & Factor A & Factor B & \% Reduction in DOC \\
\hline 1 & 25 & 470 & 74 \\
2 & 100 & 470 & 81 \\
3 & 25 & 508 & 72 \\
4 & 100 & 508 & 78 \\
5 & 50 & 439 & 74 \\
6 & 50 & 439 & 73 \\
7 & 50 & 439 & 76 \\
8 & 50 & 439 & 74 \\
\hline
\end{tabular}

Table 7. Analysis variance (ANOVA) obtained from the average of DOC reduction values according to the experimental factorial matrix $2^{2}$ for catalytic ozonization treatment.

\begin{tabular}{l|ccccc}
\hline \multicolumn{1}{c|}{ Factors } & $\begin{array}{c}\text { Sum of } \\
\text { Squares }\end{array}$ & $\begin{array}{c}\text { Degrees of } \\
\text { Freedom }\end{array}$ & $\begin{array}{c}\text { Mean sum of } \\
\text { Squares }\end{array}$ & F & P \\
\hline $\mathrm{A}-\mathrm{Fe}^{3+}$ & 42.7 & 1 & 42.7 & 169 & 0.000981 \\
${\mathrm{~B}-\mathrm{O}_{3}}$ & 7.3 & 1 & 7.3 & 29 & 0.012547 \\
Interactions (AB) & 10.9 & 1 & 10.9 & 43 & 0.007146 \\
Error & 0.76 & 3 & 0.3 & & \\
Total & $\mathbf{6 1 . 7}$ & $\mathbf{6}$ & & & \\
\hline
\end{tabular}

Such findings indicated that increasing the $\mathrm{Fe}^{3+}$ catalyst concentration to $100 \mathrm{mg} \mathrm{L}^{-1}$ is statistically significant in promoting interactions of metal ions and an oxidizing agent at $>95 \%$ confidence. The data in Column $\mathrm{F}$ indicate that Interactions $\mathrm{AB}$ are statistically more important than those for Factor $\mathrm{B}-\mathrm{O}_{3}$.

It can therefore be inferred that the degradation of the organic matter constituent occurs either by hydroxyl radicals generated by catalytic ozonization or by homogeneous molecular 
SOUZA, A. L.; IZARIO FILHO, H. J.; PEIXOTO, A. L. C.; GUIMARAES, O. L. C.; LOURES, C. C. A.; LAMAS SAMANAMUD, G. R.; SILVA, M. B. Effects of ferric ions on the catalytic ozonation process on sanitary landfill leachates. .Ambi-Agua, Taubaté, v. 8, n. 1, p. 48-61, 2013. (http://dx.doi.org/10.4136/ambiagua.958)

ozone. The mechanism of degradation by hydroxyl radicals is more significant than the attack of organic molecules through molecular ozone if the catalyst and ozone ratio is adjusted.

Figure 1 shows the profiles for mineralization of the organic matter constituents in the leachate flow as a function of metallic-ion ozone concentration. The exponential profiles of leachate organic load degradation from catalytic ozonation are shown in blocks for easier viewing and discussion. These are further divided into two groups according to the percentage reduction of DOC: 1) Four experiments with the lowest percentage1, 3, 6 and 8; and 2) four experiments with the largest percentage of DOC 2, 4, 5 and 7 . In the first block, the percentage reduction DOC ranged from $72.0 \%$ to $74.3 \%$. Experiment 3, using low-level ferric ion concentration and high-levels of $\mathrm{O}_{3}$ generator-feed as experimental factorial matrix (Table 2), gave the lowest DOC reduction value.

Percentage reductions of DOC ranged from $72.0 \%$ to $74.3 \%$ in the first block. Experiment 3, using low-level ferric ion concentration and high-levels of $\mathrm{O}_{3}$ generator-feed as experimental factorial matrix (Table 2), resulted in the lowest DOC reduction value. Experiment 1 exhibited the most significant reduction in this block. The data differed by only two percent, however, compared to the Experiment 3 degradation where the oxygen flow and $\mathrm{Fe}^{3+}$ concentration were both at low levels.

The gas-mixture flow-feed to the generator and the concentration of ionic $\mathrm{Fe}^{3+}$ were $470.27 \mathrm{mg} \mathrm{h}^{-1}$ and $25 \mathrm{mg} \mathrm{L}^{-1}$ for Experiment 1 and $508.34 \mathrm{mg} \mathrm{h}^{-1}$ and $25 \mathrm{mg} \mathrm{L}^{-1}$ for Experiment 3, showing significant interactions between the oxidizing agent and catalyst. From the exploratory experimental design, which included the selection of factor levels of interest optimized through the values obtained in the experimental matrix, the most viable cost-benefit treatment for leachate was selected.

Data for Experiment $6\left(438.87 \mathrm{mg} \mathrm{h}^{-1}\right.$ to $\left.50 \mathrm{mg} \mathrm{L}^{-1}\right)$ and Experiment $8\left(438.87 \mathrm{mg} \mathrm{h}^{-1}\right.$ to $50 \mathrm{mg} \mathrm{L}^{-1}$ ) were similar in reducing DOC (approximately 73.5\%). A mathematical equation was used to describe the degradations in this first group of experiments representing the optimal decay ratio for $\mathrm{DOC} / \mathrm{DOC}_{0}$ concentration over time (Figure 1).

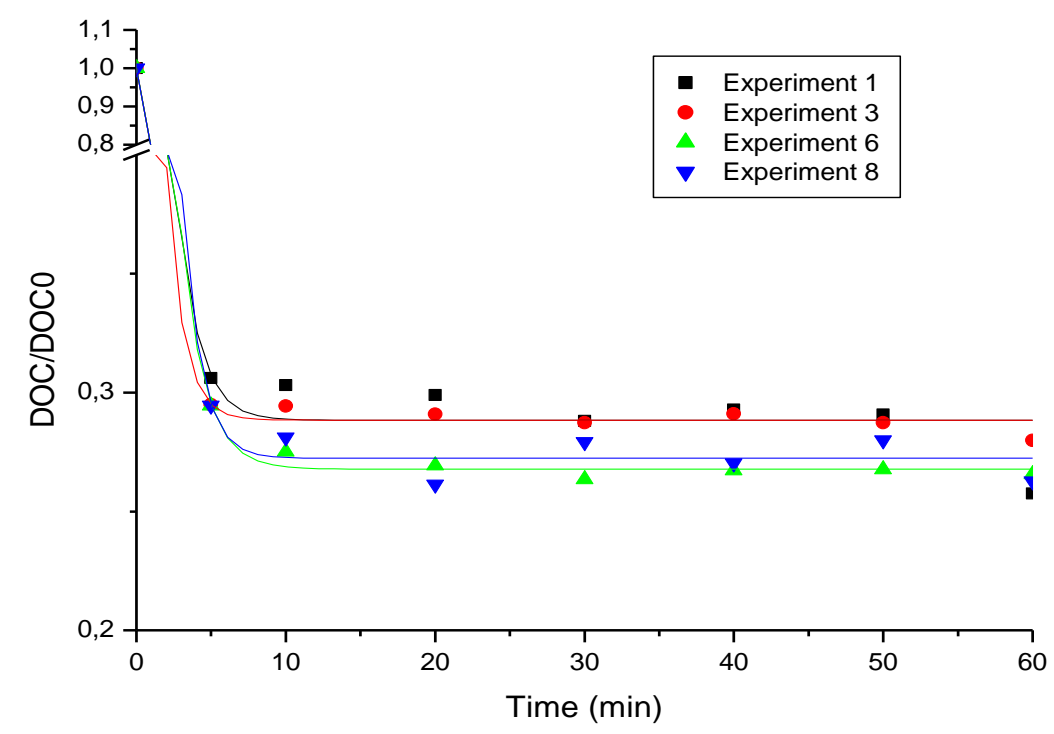

Figure 1. Degradation profiles for the oxidation process for catalytic ozonization from Experiments 1, 3, 6, and 8. 
SOUZA, A. L.; IZARIO FILHO, H. J.; PEIXOTO, A. L. C.; GUIMARAES, O. L. C.; LOURES, C. C. A.; LAMAS SAMANAMUD, G. R.; SILVA, M. B. Effects of ferric ions on the catalytic ozonation process on sanitary landfill leachates. .Ambi-Agua, Taubaté, v. 8, n. 1, p. 48-61, 2013. (http://dx.doi.org/10.4136/ambiagua.958)

The degradation profiles of the first group in Figure 1 show a realistic oxidation of $70 \%$ to $71 \%$ within the first 5 min of reaction for Experiments 1 and 3. Experiments 6 and 8 show an oxidation rate of $72 \%$ to $73 \%$ over a reaction duration of approximate 10 min. Ferric ion concentration at an optimal level was an important reaction factor in the first minutes. Figure 1 shows that the $\mathrm{Fe}^{3+}$ variable provided the most significant effect at a level of $95 \%$ (Column P). The second set of experiments showed the highest percentages of DOC reduction as seen in Figure 2. All experiments in this block were fitted with the Boltzman sigmoidal function at $\mathrm{R}^{2}>0.997$.

The second experiment saw featured the reaction occurring within the first $10 \mathrm{~min}$, after which there was no significant further reaction. Other experiments in this block produced reactions occurring within the first $5 \mathrm{~min}$.

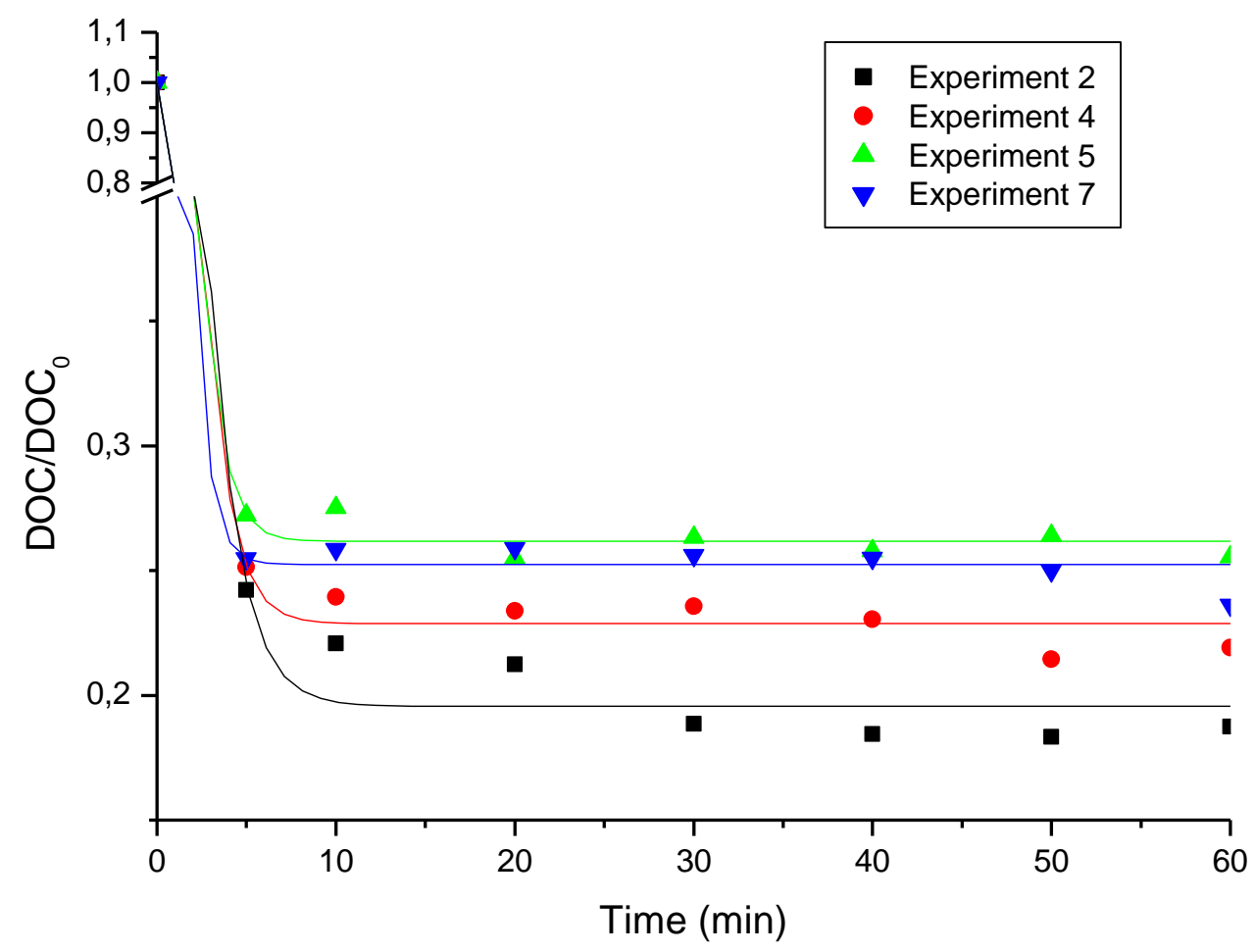

Figure 2. Sections of leachate degradation by oxidation under the catalytic ozonization process for Experiments 2, 4, 5, and 7.

Table 6 shows the highest ratio of DOC reduction observed in Experiment 2 under high $\mathrm{Fe}^{3+}$ level (Table 2) with a low level $\mathrm{O}_{3}$ generator-feed reaching an approximate value of $81.25 \%$. Experiment 4 showed a DOC reduction value of $78.08 \%$.

High levels of ferric ion concentrations were matched by high levels of generated $\mathrm{O}^{3}\left(\mathrm{mg} \mathrm{h}^{-1}\right)$ (Table 2). This shows that the influence of $\mathrm{Fe}^{3+}$ is critical to the degradation of the leachate slurry through the oxidative process, regardless of the high-level oxygen feed-stream flow (shown in Table 6). 
SOUZA, A. L.; IZARIO FILHO, H. J.; PEIXOTO, A. L. C.; GUIMARAES, O. L. C.; LOURES, C. C. A.; LAMAS SAMANAMUD, G. R.; SILVA, M. B. Effects of ferric ions on the catalytic ozonation process on sanitary landfill leachates. .Ambi-Agua, Taubaté, v. 8, n. 1, p. 48-61, 2013. (http://dx.doi.org/10.4136/ambiagua.958)

Experiments 5 and 7 were conducted with both previously noted factors at the same level (intermediate) (shown in Table 2) and demonstrated little variation. Experiment 5 produced a reduction rate of $74.45 \%$ and Experiment 7 exhibited an approximately value of $76.38 \%$.

Data from the second set of experiments resulted in no correlation to the adjustment of DOC. The correlations for Experiments 2 and 4 were $\mathrm{R}^{2}>0.99$ and for Experiments 5 and 7 were $\mathrm{R}^{2}<0.9$.

\subsection{Economic evaluation of the catalytic ozonation process.}

The economic evaluation of leachate treatment processes presented here addresses energy consumption and the use of chemical reagents without regard to the stage of coagulation/flocculation of ferric ion. The precipitation and filtration of iron are necessary criteria to meet the requirements of environmental legislation. However, his falls outside the scope of this work. Moreover, post-catalytic iron can be reused for various industry segments, e.g., the manufacture of ceramic materials in civil construction.

Ozone was generated by dielectric barrier (corona), converting $\mathrm{O}_{2}\left(99.5 \%\right.$ purity) into $\mathrm{O}_{3}$. The $\mathrm{pH}$ monitoring was performed with a Hanna ${ }^{\mathrm{TM}}$, Model HI 2221 (5000 mA, 12 VDC, $220 \mathrm{~V}, 50-60 \mathrm{~Hz}$ ). The thermostatic bath was a Quimis ${ }^{\mathrm{TM}}$, Model Q214S (nominal volume 10 1 of water, cooling capacity of $\left.3000 \mathrm{BTU} \mathrm{h}^{-1}, 2100 \mathrm{~W}, 220 \mathrm{~V}\right)$.

The estimated energy consumption of these devices was determined by measuring the optimized-reaction time for each experimental condition, using the tested equipment and ICEL $^{\mathrm{TM}}$ power-consumption meter Model ME-2500 $(220 \mathrm{~V}, 60 \mathrm{~Hz})$ under a Certificate of Conformity (Table 8). Temperature-controlled energy consumption was measured from the initial instance of the thermostatic bath reaching $25^{\circ} \mathrm{C}$.

Table 8. Energy consumption in the reaction of catalytic ozonation for $2^{2}$ factorial design on 900 $\mathrm{ml}$ leachate samples.

\begin{tabular}{l|ccc}
\hline \multirow{2}{*}{\multicolumn{1}{c|}{ Operational Step }} & \multicolumn{3}{|c}{$\begin{array}{c}\text { Equipment } \\
\text { (kWh) }\end{array}$} \\
\cline { 2 - 4 } & Bath Thermostat & Ozonator & pH meter \\
\hline $\mathrm{pH}$ Control & - & - & 0.00083 \\
$\mathrm{O}_{2}$ and $\mathrm{O}_{3}$ Gas-flow Meter & 1.02 & 0.048 & - \\
Temperature Control & & - & \\
\hline
\end{tabular}

As per Table 8, the thermostatic bath consumed the most power followed by the ozonator. Note that the ozone generator power consumption is independent of the value of mass flow of oxidant, as shown above. All experiments were conducted at a constant temperature of $25^{\circ} \mathrm{C}$.

Consideration was also given for reagent additives and the estimated consumption of the following reagents: $\mathrm{H}_{2} \mathrm{SO}_{4}(98 \% \mathrm{w} / \mathrm{w}) \mathrm{NaOH}(98 \% \mathrm{w} / \mathrm{w})$ and $\mathrm{Fe}_{2}\left(\mathrm{SO}_{4}\right)_{3} \cdot 7 \mathrm{H}_{2} \mathrm{O}(98 \%$ w/w $)$.

Table 9 shows the amount of reagents listed in the experimental factorial matrix $2^{2}$ (Table 2) regarding catalytic ozonization treatment for leachate. 
SOUZA, A. L.; IZARIO FILHO, H. J.; PEIXOTO, A. L. C.; GUIMARAES, O. L. C.; LOURES, C. C. A.; LAMAS SAMANAMUD, G. R.; SILVA, M. B. Effects of ferric ions on the catalytic ozonation process on sanitary landfill leachates. .Ambi-Agua, Taubaté, v. 8, n. 1, p. 48-61, 2013. (http://dx.doi.org/10.4136/ambiagua.958)

Table 9. Amount of reagents used in catalytic ozonation reactions as factorial matrix $2^{2}$ for samples of $900 \mathrm{ml}$ of leachate and time optimized for each experimental condition tested.

\begin{tabular}{|c|c|c|c|c|c|}
\hline \multirow{2}{*}{ Operational Steps } & \multirow{2}{*}{$\begin{array}{c}\text { Variable } \\
\text { Level }\end{array}$} & \multicolumn{4}{|c|}{ Reagent mass (g) } \\
\hline & & $\mathbf{O}_{2}$ & $\mathrm{Fe}_{2}\left(\mathrm{SO}_{4}\right)_{3}$ & $\mathrm{H}_{2} \mathrm{SO}_{4}$ & $\mathrm{NaOH}$ \\
\hline Solubilization for $\mathrm{Fe}_{2}\left(\mathrm{SO}_{4}\right)_{3} \cdot 7 \mathrm{H}_{2} \mathrm{O}$ & $\begin{array}{l}1 \\
2 \\
3\end{array}$ & & & $\begin{array}{c}6.77 \\
13.04 \\
25.60\end{array}$ & \\
\hline pH Adjustment & $\begin{array}{l}1 \\
2 \\
3\end{array}$ & & $\begin{array}{l}0.5 \\
0.5 \\
0.5\end{array}$ & & $\begin{array}{l}1.2 \\
1.2 \\
1.2\end{array}$ \\
\hline Catalytic Ozonation & $\begin{array}{l}\mathbf{1} \\
\mathbf{2} \\
\mathbf{3}\end{array}$ & $\begin{array}{l}0.0204 \\
0.0408 \\
0,0612\end{array}$ & $\begin{array}{c}5.68 \\
11.36 \\
22,73\end{array}$ & & \\
\hline
\end{tabular}

Table 10 shows the energy profile for the homogeneous catalytic ozonation experiments as per the experimental matrix presented in Table 1.

Table 10. Consumption of energy and reagents for $900 \mathrm{ml}$ of leachate treated by homogeneous catalytic ozonation process for the experimental factorial matrix $2^{2}$.

\begin{tabular}{c|ccccc}
\hline Experiment & $\begin{array}{c}\text { Energy } \\
\text { Consumption } \\
\text { US\$/900 ml }\end{array}$ & $\begin{array}{c}\text { Reagent } \\
\text { Consumption } \\
\mathbf{U S}^{* * * * *} / \mathbf{9 0 0} \mathbf{~ m l}\end{array}$ & $\begin{array}{c}\text { TotalValue } \\
\text { US\$/900 } \mathbf{~ m l}\end{array}$ & $\begin{array}{c}\text { DOC } \\
\text { Reduction } \\
\mathbf{\%}\end{array}$ & $\begin{array}{c}\text { Ratio of } \\
\text { US\$/\%DOC } \\
(\mathbf{x 1 0 0 0})^{* * * * *}\end{array}$ \\
\hline $\mathbf{1}$ & 0.14315 & 0.06336 & 0.20651 & 74.25 & 2.78 \\
$\mathbf{2}$ & 0.14315 & 0.18817 & 0.33132 & 81.25 & 4.07 \\
$\mathbf{3}$ & 0.14315 & 0.13843 & 0.28158 & 72.01 & 3.91 \\
$\mathbf{4}$ & 0.14315 & 0.18817 & 0.33132 & 78.08 & 4.24 \\
$\mathbf{5}$ & 0.14315 & 0.117459 & 0.26060 & 74.45 & 3.50 \\
$\mathbf{6}$ & 0.14315 & 0.117459 & 0.26060 & 73.44 & 3.54 \\
$\mathbf{7}$ & 0.14315 & 0.117459 & 0.26060 & 76.38 & 3.41 \\
$\mathbf{8}$ & 0.14315 & 0.117459 & 0.26060 & 73.73 & 3.53 \\
\hline
\end{tabular}

$* 1 \mathrm{kWh}=\mathrm{US} \$ 0.133$; Electrical energy at the third highest cost in Brazil (Portal Business Brazil, 2011).

***uote $\mathrm{N}^{\circ} 212712$ from Labsynth Produtos para Laboratórios Ltda, 23 October 2011.

$* * *$ US\$ $1.00=\mathrm{R} \$ 1,847$ (UOL, 2011).

$* * * *$ Factor for additional evaluations.

Generally, Table 10 results showed the best value of the process (reduction of $81.3 \%$ organic matter) and had the seventh highest cost-benefit ratio $(4.07 \times 3.10$ U.S. \$/\% DOC). Experiment 4 showed the second best result of the process $(78.1 \%$ degradation of the DOC concentration) and had the highest cost-benefit ratio of 4.24.

Another relevant factor for Table 10 data was the cost of inputs (reagents) being higher in relation to energy, except for Experiments 2 and 4, which exhibited greater cost/benefit ratios. Importantly, the purchase of reagents in small quantities is more expensive than bulk-buying and costs may be lower when using reagents of a lower analytical grade provided there is no 
SOUZA, A. L.; IZARIO FILHO, H. J.; PEIXOTO, A. L. C.; GUIMARAES, O. L. C.; LOURES, C. C. A.; LAMAS SAMANAMUD, G. R.; SILVA, M. B. Effects of ferric ions on the catalytic ozonation process on sanitary landfill leachates. .Ambi-Agua, Taubaté, v. 8, n. 1, p. 48-61, 2013. (http://dx.doi.org/10.4136/ambiagua.958)

qualitative impact. A PA reagent was used as a process additive in bench trials with the understanding that an industrial-grade substitute would have been cheaper. Note that chemical reagents must avoid chlorine, carbonate, and bicarbonate contamination which act as scavengers of reactive hydroxyls.

The catalytic ozonation process analyzed in Experiment 2 provided a reduction greater than $80 \%$, meeting federal legislation for treated leachate targeted for release directly into waterways.

Importantly, the oxidation process in Experiments 2, 6, and 8 occurred within the first 10 min. From these experiments, only Experiment 2 showed a higher cost- benefit ratio. Note that the oxidation process for Experiments 1, 3, 4, 5, and 7 occurred within the first 5 minutes. Experiment 1 provided a DOC reduction of $74.25 \%$ and also had the lowest cost-benefit ratio. A low-level of ferric iron concentration was utilized in Experiment 1.

Table 10 shows the treatment process to be exceptionally expensive for Experiments 2 and 4, while having the highest DOC reduction for the $900 \mathrm{ml}$ sample. All experiments show that there was practically no further organic matter mineralization after 5 or $10 \mathrm{~min}$. Ideally, use of the first experiment (the most cost-effective) will require the lowest concentration of both catalyst and ozone.

\section{CONCLUSIONS}

The physical-chemical parameters of leachate in natura showed relatively high concentrations of $\mathrm{BOD}_{5}\left(476.1 \mathrm{mg} \mathrm{O}_{2} \mathrm{~L}^{-1}\right)$, COD $\left(1032 \mathrm{mg} \mathrm{O}_{2} \mathrm{~L}^{-1}\right)$ and DOC $\left(465.5 \mathrm{mg} \mathrm{L}^{-1}\right)$. These are within the regulatory standards of federal legislation and therir release is permitted in waterways.

The landfill leachate from the City of Cachoeira Paulista showed BOD5/COD $=0.45$. Although this value is close to 0.5 , there is no guarantee that the leachate could be biologically treated to reach acceptable levels of waterway release. It was found that biological degradation was not efficient and, consequently, AOP treatment is required using an experimental factorial matrix $2^{2}$. Thus, this procedure provided the best results for the decrease of DOC and may be concluded to be advantageous in terms of cost-benefit applications for organic matter reduction. As shown by BOD/COD ratio, organic matter is not always environmentally friendly and pursuit of more effective leachate treatments would ideally incorporate the lowest concentrations of ozone. Further experiments with higher concentrations of $\mathrm{Fe}^{3+}$ would also be worthwhile as surface reduction of DOC was demonstrated under increasing concentrations of ferric iron in addition to decreasing concentrations of ozone for a higher reduction of DOC. Therefore, further work is required for the environmentally-safe disposal of leachates into waterways.

\section{REFERENCES}

AMOKRANE, A.; COMEL, C.; VERON, J. Landfill leachates pretreatment by coagulationflocculation. Water Research, v. 31, n. 11, p. 2775-2782, 1997. http://dx.doi.org/ 10.1016/S0043-1354(97)00147-4

ASSALIN, M. R.; DURAN, N. Novas tendências para aplicação de ozônio no tratamento de resíduos: ozonização catalítica. Revista Analytica, São Paulo, v. 26, p. 76-86, 2007. 
CAETANO, M. O. Aplicação do reator de chicanas no tratamento de aterros sanitários de resíduos sólidos urbanos para remoção de nitrogênio amoniacal por “stripping". 2009, 167f. Dissertação (Mestrado em Engenharia Civil) - Universidade do Vale do Rio dos Sinos - UNISINOS, São Leopoldo, 2009.

CALLI, B.; MERTOGLU, B.; INANC, B. Landfill leachate management in Istanbul: applications and alternatives. Chemosphere, v. 59, n. 6, p. 819-829, 2005. http://dx.doi.org/10.1016/j.chemosphere.2004.10.064

CASTILHOS JR., A. B. Gerenciamentos de resíduos sólidos urbanos com ênfase na proteção de corpos d'água: prevenção, geração e tratamento de lixiviados de aterros sanitários. Rio de Janeiro: ABES, 2006.

COSTA, P. O. S. Avaliação em laboratório, do transporte de contaminantes no solo do aterro sanitário de Sauípe/BA. 2002, 188f. Dissertação (Mestrado em Engenharia Civil) - Pontifica Universidade Católica-Rio, Rio de Janeiro, 2002.

KASPRZYK-HORDERN, B.; ZIOLEK, M.; NAWROCKI, J. Catalytic ozonation and methods of enhancing molecular ozone reactions in water treatment. Applied Catalysis B: Environmental, v. 46, n. 4, p. 639-669, 2003. http://dx.doi.org/10.1016/S09263373(03)00326-6

JAVIER RIVAS, F.; BELTRAN, F.; CARVALHO, F.; ACEDO, B.; GIMENO, O. Stabilized leachates: sequential coagulation-flocculation + chemical oxidation process. Journal of Hazardous Materials, v. 116, n. 1/2, p. 95-102, 2004. http://dx.doi.org/ 10.1016/j.jhazmat.2004.07.022

LEGUBE, B.; LEITNER, N. K. V. Catalytic ozonization: a promising advanced oxidation technology for water treatment. Catalysis Today, v. 53, n. 1, p. 61-72, 1999. http://dx.doi.org/10.1016/S0920-5861(99)00103-0

MARTTINEN, S. K.; KETTUNEN, R. H.; SORMUNEN, K. M.; SOIMASUO, R. M.; RINTALA, J. A. Screening of physical-chemical methods for removal of organic material, nitrogen and toxicity from low strength landfill leachates. Chemosphere, v. 46, n. 6, p. 851-858, 2002. http://dx.doi.org/10.1016/S0045-6535(01)00150-3

MONJE-RAMIREZ, I.; ORTA DE VELASQUEZ, M. T. Removal and transformation of recalcitrant organic matter from stabilized saline landfill leachates by coagulationozonation coupling processes. Water Research, v.38, n. 9, p. 2359-2367, 2004. http://dx.doi.org/10.1016/j.watres.2004.02.011

OZTURK, I.; ALTINBAS, M.; KOYUNCU, I.; ARIKAN, O.; GOMEC-YANGIN, C. Advanced physico-chemical treatment experiences on young municipal landfill leachates. Waste Management, v. 23, n. 5, p. 441-446, 2003. http://dx.doi.org/ 10.1016/S0956-053X(03)00061-8

PEIXOTO, A. L. C. Ozonização catalítica do chorume proveniente do antigo aterro controlado da cidade de Guaratinguetá - SP utilizando os íons $\mathrm{Fe}^{2+}, \mathrm{Fe}^{3+}, \mathrm{Zn}^{2+}$, $\mathbf{M n}^{2+}, \mathbf{N i}^{2+} \mathbf{e ~ C r}^{3+}$. 2008. 211f. Dissertação (Mestrado em Engenharia Química) - Escola de Engenharia de Lorena, Universidade de São Paulo, Lorena, 2008. 
SOUZA, A. L.; IZARIO FILHO, H. J.; PEIXOTO, A. L. C.; GUIMARAES, O. L. C.; LOURES, C. C. A.; LAMAS SAMANAMUD, G. R.; SILVA, M. B. Effects of ferric ions on the catalytic ozonation process on sanitary landfill leachates. .Ambi-Agua, Taubaté, v. 8, n. 1, p. 48-61, 2013. (http://dx.doi.org/10.4136/ambiagua.958)

POHLAND, F. G.; HARPER, S. R. Critical review and summary of leachate and gas production from landfills. Cincinnati: U.S. Environmental Protection Agency, 1986. Report N EPA/600/2-86/073, U.S.A. EPA.

PORTAL BUSINESS BRASIL. Energia elétrica a terceira mais caro do Brasil. 2011. Available in: <https://sites.google.com/site/portalbusinessbrasil/home/energiabrasileira> Access in: Nov. 2011.

RITA, F. Desempenho de um Reator UASB em escala piloto para o tratamento anaeróbio de líquidos percolados de resíduos sólidos urbanos. 2002. Dissertação (Mestrado em Engenharia Química) - Universidade Federal de Santa Catarina, Florianópolis, 2002.

SHEN, Y-S.; WANG, D-K. Development of photoreactor design equation for the treatment of dye wastewater by $\mathrm{UV} / \mathrm{H}_{2} \mathrm{O}_{2}$ process. Journal of Hazardous Materials, v. 89, n. 2/3, p. 267-277, 2002. http://dx.doi.org/10.1016/S0304-3894(01)00317-X

SOUTO, G. D. B.; POVINELLI, J. Características do lixiviado de aterros danitários no Brasil. In: CONGRESSO BRASILEIRO DE ENGENHARIA SANITÁRIA E AMBIENTAL, 24., 2006, Belo Horizonte. Anais ... Belo Horizonte: ABES, 2006

UOL. Currency quote. 2011. Available in: <http://economia.uol.com.br/cotacoes>. Access in: Nov. 2011.

VOGEL, A. I. Química analítica quantitativa. 5. ed. Sao Paulo: Guanabara Koogan, 1981.

WU, J. J.; WU, C-C.; MA, H-W.; CHANG, C-C. Treatment of landfill leachate by ozonebased advanced oxidation process. Chemosphere, v. 54, n. 7, p. 997-1003, 2004. http://dx.doi.org/10.1016/j.chemosphere.2003.10.006 